\title{
THE ETHNICIZATION OF POLITICS AND THE POLITICIZATION OF ETHNICITY: CULTURE AND POLITICAL DEVELOPMENT IN SOUTH AFRICA
}

\author{
Preben Kaarsholm
}

The thoughts contained in this paper were first tried out in the context of a workshop on "Gender and Ethnicity in a Modernizing World" which was organized by the Centre for Development Research, Copenhagen, in collaboration with International Development Studies, Roskilde, in February 1992. The paper represents a stage of further reflection and has been able to benefit from the very valuable discussions which took place at the Copenhagen workshop.

Initially, let me put forward a few words of clarification regarding the status of "ethnicity" as a category of social identification. I would agree with a statement made by Karen Hansen during the Copenhagen workshop that gender and ethnicity do not automatically sit easily together on an agenda for discussion. 1 They seem to constitute different layers or levels within the complex of multiple identities and bases for cultural and political mobilization that we really seem to be discussing. In a context of overlapping, fluctuating, shifting and mutually interlinked identifications according to signifiers like class, language, religion, caste, generation, clan affiliation, social movement or ideological attachment, or whatever other register might be set as relevant, gender appears to constitute a more basic level of identity or differentiation, underlying and interacting with other layers but presenting different problems for a discussion of possibilities and obstacles for politicization. Thus, in his book The Remembered Village, the Indian anthropologist M. N. Srinivas describes how differences of gender overruled those of caste and religion in his Mysore village even as the chaos of partition was at its height in 1947-48.2 And Norma Kriger, in her recent study of struggles within the struggle of the Zimbabwean war of decolonization, demonstrates that of all the fronts that were opened within the war, between generations, lineages, etc., the one over gender issues was the one whose battles brought about the least change. ${ }^{3}$ Thus, while it may make sense to discuss how gender gets modelled and articulated through discourses of ethnicity, it is misleading to think of gender and ethnicity as constituting parallel types of "primordial identity" which can be theorized and approached methodologically in the same way.

But this is by the by. In these brief remarks, I shall focus on ethnicity as a level of discourse, identification and creation of difference which can be drawn upon and prioritized in processes of political mobilization, and consider some of the consequences such politicization may have for the understanding and function of ethnicity.

According to the assumptions of "classical" modernization theory, American and West European thinking about relations between economic, social, political and cultural development of the 1950s and 1960s, "traditional" cultural differentiations and the ascription of particular social functions to particular social groups would become eroded in the process of economic modernization and give way to anonymized, individualized and empathy-oriented modes of outlook and self-understanding which would again provide the precondition for the emergence of modern types of participatory and equality-based systems of political representation and government. 4 This was seen as a unidirectional process which was "tragic" inasmuch as it replaced a world of dense cultural riches with an "iron cage" of secularized rationality and atomization; more importantly, however, it was regarded as one of liberating human potential from the shackles of arbitrarily assigned ascriptions and limitations. ${ }^{5}$ A similarly unidirectional view has been characteristic of Marxist theories of modernization, which have tended to regard ethnicity not so much as a "genie in a bottle" 6 but rather as a backward-looking, semi-fascist devil belonging to a world of ideology and rural idiocy which the development of productive forces would replace by one of rational class struggle and universalized notions of what constitutes oppression and freedom. Thus, already in 1848, Frederick Engels ridiculed Scandinavianism as a particularly retrograde mode of thinking, as drunken barbarism and brutality against women masked by sentimentality soaked in tears. ${ }^{7}$

The paradigmatic and unidirectional character of both these models has, however, been undermined by the extremely varied and broken ways in which modernization has 
progressed in different parts of the world, where any direct cause-effect relation between base and superstructure, between economic accumulation and a rise in equality, participation or socialist revolutionary potential now appears to be rather the exception than the rule: where, on the one hand, people in a variety of cases have sought refuge in modes of cultural identification and differentiation to defend themselves against the uneven consequences of modernity rather than enjoyed its unsettling and liberating effects; and where, on the other hand, political regimes have been able to use with considerable success strategies of cultural separation to consolidate power and control.

This double process of reacting or adjusting to modernization in ways which are diametrically opposed to the assumptions of modernization theory in its two major "classical" varieties has manifested itself both in societies where basic programmes of economic development have failed and in those where such development has led to accumulation, but has also been accompanied by radicalized differentiations in income and social welfare at the same time as "traditional" networks for securing reproduction have broken down.

It would be an interesting project to investigate comparatively the mobilization of ethnicity and cultural differentiation for reasons of both state control and popular resistance in countries like Uganda or Bangladesh, where hopes of modernization have been spectacularly frustrated, and in countries like Brazil, Malaysia, or South Africa, where modernization has been comparatively more successful, but also uneven and divisive.

South Africa is a particularly interesting case, since here ethnicity was deployed much more openly and programmatically than anywhere else in world, including even Israel and Malaysia. Within an originally colonial project of partial modernization, the manipulation of ethnicity was a strategy for state control and social engineering. At the same time, in South Africa, ethnicity has become crystallized as an issue in opposition to politics in a particularly clear-cut way which seems to confront two diametrically opposed conceptions of how popular aspirations are articulated most authentically and representatively. Views so radically opposed that the battle between them threatens to destroy the foundations for developing any kind of democratic political culture in South Africa, and which for this very reason is being fomented and manipulated by forces whose manifest interest rests with an absence of democracy.

One principal position is represented by the "classical" unifying nationalism of the ANC, striving for an equal vote-based, non-racial, democractic constitution and the building of an undivided nation. The most radical and coherent argument for the opposite position has been formulated by the Conservative Party and its chairman, Andries Treurnicht, the victor of the recent Potchefstrom by-election. In an attempt to link into international sympathies with federalism and sub-nationalist politics resulting from the break-up of the Soviet Union, Treurnicht told the readers of the International Herald Tribune that

\begin{abstract}
The ethnic awakening and demand for self-determination in Eastern Europe has been political practice in South Africa for the past four decades, but is now being betrayed [by a democratic dispensation where numbers necessarily will decide] ... South Africa has a deeply divided population - along racial, ethnic, cultural. language and religious lines ... To force together such largely disparate people. cultures and races. will amount to a form of tyranny, the very opposite of democratic freedom ... [instead we must promote] the development of separate freedoms for the various peoples, ethnic groups. in their own territories. or homelands. 8
\end{abstract}

In this way, conservative adherents of the preservation of apartheid can present themselves as representatives of the new - of a post-modern, cultural, relativist view of politics as opposed to the old-fashioned, centralized, modernist and tyrannically rationalist and Jacobin nationalism of the ANC.

While this contradiction between the centralized nationalism of the ANC and the ethnic nationalism of the Conservative Party is straightforward, the position of the Inkatha Freedom Party, which is trying to establish itself as representing a position alternative to both, is more ambiguous. In the process of redefining itself from a "cultural movement" to a "freedom party". Inkatha has toned down, in its public statements, the ethnic components in its programme, and has emphasized instead the organization's ambition to further a free-enterprise economy and political liberalism along lines which should make the mouth 
of any potential foreign investor (if such still exist) water. ${ }^{9}$ The preservation of cultural values continues to figure prominently on the agenda, but in a pluralist formulation - "to promote and support worthy customs and cultures of all South Africans".10 And the party is obviously keen in its public appearance to remodel its image from one of Zulu cultural nationalism to one of a more all-embracing national representation. Thus at the AGM of IFP, which I had the opportunity to attend at Ulundi in July 1991, all speeches were given in three languages - Zulu, Sotho and English - and there were violent protests from delegates when Tom Langley of the Conservative Party tried to address the meeting as one of "the Zulu nation" and convey greetings from "the Afrikaner nation": "We are not Zulus!" came the horrified shouts of white Inkatha members.

In other aspects of its political discourse, its symbolism and style of rhetoric and its everyday practice of mobilization, however, there can be no doubt about Inkatha's ethnic strategies. While the meeting at Ulundi was being treated to visions of peaceful pluralist democracy, impi warriors armed with "cultural weapons" and uniformed Youth and Women's Brigades were dancing defiantly outside the big tents, and each time the President rose to speak he was preceded by praise poets who would extol his merits as the figurehead of black African political aspirations at great length. Above all, Inkatha has worked to counteract support for the ANC in local constituencies, and this has been done to a large extent by urging and pressurizing people to organize along ethnic criteria in opposition to the "communism" and universalism of the ANC. With the support of the South African Police and the South African Defence Force, Inkatha has thus managed to divide the townships of the Rand and tracts of Natal into opposing camps violently fighting each other and subscribing not only to different political programmes but to radically different ideas of what constitutes political culture or the basic premises for political interaction. Most tragically, perhaps, it has been possible for Inkatha also to force sections of the ANC into thinking and reacting according to patterns of violent camp politics reflecting the premises of its adversary. 11

In this way, the battle between a monadic apartheid conception of politics and a universalist democratic one has been moved into the heartlands of black African communities, and, as Shula Marks has pointed out in "The Origins of Ethnic Violence in South Africa" (see note 6), the battle has been intensified by the "power vacuum" created by increased destabilization and economic crisis, of gradual dismantlement of formal and legal apartheid measures of social control and, paradoxically, by the growing possibilities for a transition from minority to majority rule.

But the situation is not only one of a "power vacuum" - it is also one of an "ideology vacuum", or, to put it differently, of a crisis of political discourse. The Indian political scientist Sudipta Kaviraj, has recently described how centralized nationalist discourse in India has disintegrated from a situation just before and after independence in which nationalist leaders were able to mediate between national and regional languages of politics and the dialects of local community political aspirations to one in which nationalist discourse has ballooned away from the understanding and articulations of ordinary people and become the exclusive domain of elite politicians. In this way a rupture has opened between an increasingly abstract sense of national belonging and increasingly hardened and particularized, modernized, notions of ethnicity and other forms of communalist identity. Where in a previous period ethnicity, like other layers of multiple identity, had a "fuzzy" nature which allowed it to be flexibly interwoven with other strands of identity formation and mobilization, it now aspires to being a monopolizing force which excludes and supersedes other markers of identity.

South Africa is obviously different from India, but there might still be parallels in the way relations between nationalism and ethnicity have developed over the last decades - from the generation of nationalist leaders like Nehru and Luthuli to the present generation of leaders returning to local politics from the outside, from exile or from prison (on Luthuli as African nationalist and Zulu leader, cf. Shula Marks, op. cit.). In any case, it seems risky to understand the battle between the political discourses of nationalism, on the one hand, and crystallized ethnicity, on the other, as only the outcome of state intervention and manipulation. There can be no doubt that the discourse of centralized African nationalism with a socialist orientation during the 1980 s has in many ways become problematized owing to its banishment from the internal South African scene, to developments of corrupt absolutism along nationalist lines in other African countries, and to the collapse of the 
"socialist" societies of Eastern Europe and the Soviet Union, and that the contours of an alternative discourse on democratic nationalism or regionalism are still very vague.

There can also be no doubt that if a transition to majority rule is effected, and an ANC-led government comes into power, such a government will face overwhelming problems of restructuring, redistribution and securing investment in a context of economic crisis as well as the tremendous difficulties resulting from intensified urbanization and pressures on resources caused by expectations aroused by the dismantlement of apartheid. It is hardly possible to be too optimistic about the possibilities of coming to terms with such problems in a situation where the institutions of political culture have systematically been eroded, and violence has ruled for so long.

So, although policies of ethnic differentiation may have been discredited as parts of apartheid strategy, and Inkatha compromised by its close links with present South African state authorities, it is hard to imagine that political mobilization according to criteria of hardened ethnicities will not play a prominent part in South African politics in the future. This obviously cannot be prevented by repressing or outlawing ethnic political organization, but may hopefully take place in circumstances where the basic premises of political culture are not broken up along lines of communalist separation, but occur rather within an institutional framework in which ethnic political parties and organizations must compete for influence with parties and organizations basing themselves on different programmes and discourses.

In this way, the most fundamental struggle in South Africa appears to be one over the basic values and institutions of political culture. Only in circumstances of a basic minimum of tolerance and the establishment of possible structures for the mediation of conflict through communication and of basic procedural rules for negotiation can one hope for a "resoftening" of ethnicity, a demobilization of its violent and xenophobic forms, and for not so much a retrogressive reintroduction of aspects of "fuzziness" as a new ironization and relativization of notions of ethnicity which will allow them to interact constructively with other backgrounds to mobilization.

It should not be forgotten that such modernized notions of ironized ethnicity are already strongly present e.g. in the popular cultures of South Africa - in instances of ethnic culture having been reduced to and compartmentalized as folklore, or cases where an ethnic idiom is played upon to give a special resonance of humour, irony or affection in otherwise "uprooted" and interculturally mixed genres of expression. Examples of this are the ways in which elements of Zulu culture have been reworked by mbube choirs 13 or by an mbaqanga group like Mhlathini and the Mahotella Queens to give expression to messages which are at once familiar and comprehensible and critically new. The image of the leopard skin-clad Mahlathini being able to stay on his feet spiritually and physically only thanks to the support of his three powerful Mahotella Queens presents a redeeming antidote to ideological notions of Zulu patriarchy, revitalizing and changing the status of the idiom rather than dismissing it. 14

In contrast with an earlier period where it was possible to understand oneself as at once a Zulu proud of one's cultural background and resistance history and as an ANC nationalist mobilizing for a South Africa liberated from apartheid, the late 1970s and the 1980s brought about a situation of frontal confrontation between centralized and ethnic nationalism. The combination of an Inkatha offensive challenging the hegemony of organizations supporting the ANC in African politics with the banishment of the major African nationalist movements from the internal political scene led to the emergence of irreconcilably differentiated types of self-understanding. Already, during the Soweto uprising of 1976, there were violent clashes between township youth supporting the rebellion and the inhabitants of ethnically segregated hostels who wanted to stay out of the fray. As such confrontations became more widespread, and were fuelled by the interventions of state agents, the ANC became increasingly "modern" and anti-ethnic in its outlook and formulations. The roots for ethnic mobilization were dismissed as simply reactionary or as the outcome of manipulations by a conspiracy of white apartheid and opportunist bantustan politicians. A good example of the type of analysis offered is provided by Mzala's book on Chief Buthelezi from 1988, which does not recognize any variety of unforced popular support for the type of ethnic nationalism represented by Inkatha. 15 
Though such an analysis was not simply incorrect, it was definitely one-sided and reductionist and overlooked the extent to which the ANC and the centralist nationalism it represented had become an abstraction in the everyday life and politics of black South Africans. In exile, and with its great unifying leader imprisoned, the political thinking of the ANC tended to petrify around notions, arguments and ideas of leadership in ways which were being challenged and rethought within left opposition movements elsewhere in the world. Thus, instead of understanding the challenge of ethnic nationalist mobilization dialectically as the outcome of both conservative manipulation and grassroots frustration with other available channels of political articulation and responding to it correspondingly, the ANC tended to dismiss the ethnicization of politics out of hand and counter it with a programme of democratic nation-building for the whole South Africa, which did not take community differentiation and grievances of communication into account and provided little more than abstract meaning and a set of symbolic rallying points for local constituencies. At the same time, the post-1985 campaign to make local communities "ungovernable" and set up alternative structures of counter-hegemony on behalf of the ANC "camp", in parallel with the separatist offensive of Inkatha, served to confront centralist and ethnic nationalisms as irreconcilably different platforms for mobilization and to escalate the violence undermining possibilities for the development of a democratic political culture.

Only belatedly did the ANC begin to take the ethnic challenge seriously; since then it has been attempting through the Congress of Traditional Leaders of South Africa (CONTRALESA) and new tactical alliances with some of the homelands governments to challenge Inkatha's usurpation and monopolization of "traditional" and ethnic articulations and potentials. This coincided, more or less, with the first attempts within the ANC to come to terms with the upheavals and clamours for democratic reform which in the late 1980s were erupting with unpredictable force in Eastern Europe and the Soviet Union, and which forced the organization to confront critically the ideological legacy of "the Second World" that had provided its main moral, political and economic support throughout the period of exile, and thereby also the "centralism" of its own leadership within the struggle for a democratic South Africa.

Thus, in a 1989 working paper, the general secretary of the South African Communist Party and former head of Umkhonto we Sizwe (the ANC's military wing), Joe Slovo, critically addressed the dogmatism which had come to characterize the political theory of the South African left and its reliance on outdated and disputable notions of the need for a "dictatorship of the proletariat", a "vanguard party" and the benefit of a one-party state to replace the apartheid caricature of "bourgeois" parliamentary democracy. 16 Slovo criticized, further, policies based on the "big bang theory of socialism" and argued that "many ingredients of social systems which succeed one another ... cannot be separated by a Chinese Wall". The outcome of his argument was that the nationalist and socialist struggle must be one for "multi-party post-apartheid democracy" and for "political pluralism" involving a guarantee for all citizens of "the basic rights and freedoms of organization, speech, thought, press, movement, residence, conscience, and religion".

Slovo's paper said little, however, about how these values and goals could be promoted when the ANC was already in the process of fighting for them; and it is not clear from his formulations to what extent ethnic forms of organization and mobilization would be acceptable elements of the new pluralism. Concerning such issues, "Preparing for Freedom", an ANC discussion paper prepared by Albie Sachs in late 1989, is more articulate and provocative. 17 For Sachs, "the method is the message" in the struggle against apartheid (p 24 ), and this implies that pluralism must be not only a distant goal of the future but also a characteristic of nationalist political mobilization here and now:

... we exercise true leadership in being non-hegemonic, by selflessly trying to create the widest unity of the oppressed and to encourage all forces for change, by showing the people that we are fighting not to impose a view upon them but to give them the right to choose the kind of society they want and the kind of government they want. (p 28)

The call is not

for a homogenised South Africa made up of identikit citizens ... we [must] envisage [South Africa] as a multi-lingual country. It will be multi-faith and multi-cultural as well. The objective is not to create a model culture into which everyone has to 


\begin{abstract}
assimilate, but to acknowledge and take pride in the cultural variety of our people. In the past, attempts were made to force everyone into the mould of the English gentleman, projected as the epitome of civilisation, so that it was an honour to be oppressed by the English. Apartheid philosophy, on the other, hand, denied any common humanity and insisted that people be compartmentalised into groups forcibly kept apart. In rejecting apartheid, we do not envisage a return to a modified form of the British imperialist notion, we do not plan to build a non-racial yuppie-dom which people may enter only by shedding and suppressing the cultural heritage of their specific community. (p 24f.)
\end{abstract}

On the other hand, Sachs refuses to accept - either in the struggle or in the envisaged future democratic dispensation - forms of "tribal chauvinism" and "ethnic exclusiveness" (pp 26 and 27) which do not recognize a minimum set of nationally universal institutions, rights and regulations within "a single South Africa" (p 24).

While the unified nation is thus still the fundamental frame of reference for political imagination, and the boundaries between "exclusive" and legitimate ethnic organization may be difficult to draw exactly, Albie Sachs's paper does indeed appear to draft an agenda for a new and different political culture as the necessary base for a functioning democracy. In the context of this vision, one could imagine an "unhardening" of ethnicity which would allow it to act as a focus for organization, and even as the basis for the founding of political parties, alongside organizations bringing people together according to alternative criteria of social identity.

Another tendency which might, paradoxically, help to further an "unhardening" of ethnicity, is the growing awareness of the way in which certain types of ethnic organizations have been turned into direct instruments of state violence against the opposition in South Africa. The hearings of the Goldstone Commission and the stubborn journalistic campaigns of journals like the Weekly Mail, the New Nation and the Vrye Weekblad have unearthed increasingly hard evidence that the South African Police and the South African Defence Force have been co-operating extensively with the Inkatha Freedom Party in an effort to ethnicize the premises of township politics into basically confrontations between Zulu and Xhosa. This has, typically, taken the form of Inkatha's mobilizing or pressuring hostel-dwelling migrant labourers into hit squads which have then been trained by police or army personnel to attack ANC meetings, leaders or sympathizers, or to engage in acts of random violence and killing with the intention of destablizing any "normal" and peaceful build-up of oppositional political culture and procedure in black African communities. 18

While the immediate outcome of such bloody intervention and ethnicization of politics is to make the establishment of the foundations of a tolerant and pluralist alternative political culture along Albie Sachsian lines extremely difficult, the more long-term effect, if the violence is brought under control and its background fully clarified, might be to expose the joint Inkatha-South African security force mobilization as representing a very particular type of politicization of ethnicity, which is as destructive to other forms of locality- and language-based loyalties as it aims to be to non-ethnic nationalist organization. The exposure and awareness of the special character of Inkatha's uses of notions of ethnicity for narrow purposes of state manipulation might therefore, in the end, help to open up the political field to other varieties of ethnic discourse, and to organization of a more peaceful and "unhardened" type which would be able to interact with differently based groupings within the framework of a commonly agreed political cultural consensus. 19

The need to take ethnicity and locally-based cultures and political languages seriously is related to the possibilities for entering into dialogue with and representing some of the poorest and weakest groups in society - the rural proletariat, migrant workers and, not least, women, who have had restricted access to education and to central national languages, and whose needs therefore tend to remain unarticulated and disregarded unless their local languages and cultural terms of reference are taken into account. This is a point which has recently been made quite convincingly by Luke Mhlaba in the context of political and cultural development in Zimbabwe. 20 Mhlaba not only argues the need to support the development of local language strategies in education, media production and cultural policy in order to provide democratic possibilities for all groups in society, but also the necessity of reducing the concentration of political power at central national state level and of working 
instead towards more federalist forms of government with a high degree of power delegated to provincial and local levels.

While federalism, in the case of South Africa, has attained a bad name because of its association with apartheid strategies of working towards a basically racist and economically unjust union of semi-independent "homelands", and the belief in the necessity of "a single South Africa", a firm credo of African nationalist and anti-apartheid politicians, future developments in the greater southern African region might eventually bring into question, in a new way, the representational and economic adequacy of present political boundaries and national state levels. If South Africa is democratized, and restrictions on trade, investment and other forms of economic interaction reduced, it might come to make sense to reduce the influence of present-day national states in favour of new institutions of government to be built up at regional level. This, in turn, would require a substantial reform and expansion of representational and administrative institutions at the local level, which might provide the opportunity for rethinking the issue of federalism with a view to providing political structures with a higher degree of legitimacy and responsiveness vis-à-vis the poorest and weakest groups in society. Such a development, again, might help to dismantle and "unharden" the opposition between nationalist and ethnic political principles as it exists today and would require presently nationalist politicians to develop both programmes and discourses that are more sensitive to local needs and understandings.

The speeches made and documents presented at the Ulundi Annual General Meeting of the Inkatha Freedom Party in 1991 demonstrated an awareness on the part of Chief Buthelezi and his organization that groups such as women who are weak in terms of access to national cultural resources provide them with a particularly promising base for recruitment. Thus, in the section of his central speech dealing with "The role of women in the politics of change", Buthelezi emphasized the special relationship which exists between himself as leader and the women of his party: "In the IFP women have always been the backbone of my political support, and of the resilience of our Party ... If women allow themselves to be dragged on behind male-dominated political Parties, they will be authoring their own deprivation in the future." [21] At the same time, in spite of these almost feminist exhortations, the messages addressed specifically to women demonstrated how central gender issues are in the construction of ethnic political ideology. Thus, when Buthelezi referred to "a whole new social class of persons" having been brought into being by apartheid - "the unmarried black mothers" - he was activating the ideological tenets of the family and the homestead which Jeff Guy has been describing, the virtues of a cultural traditionalism which have come under threat from both a "modernist" government and from left nationalist politicians who are betraying their cultural roots.

While gender and ethnicity do thus represent types of identity formation which are in many ways different and require different approaches of exploration, they also represent ideological registers and discourses which are interwoven in the terrain of local, everyday-life politics. If this terrain is neglected as an arena for articulation and interaction by nationalist politicians, it is left open for monopolization by other forces whose aims in ethnicisizing politics are not necessarily those of working towards democracy.

\section{NOTES}

1 Cf. Karen Tranberg Hansen, "Ethnicity and Gender in Zambia: What Kind of Relationship?", in the collection of papers presented at the workshop on Gender and Ethnicity in a Modernising World (Copenhagen, February 1992).

$2 \quad$ M. N. Srinivas, The Remembered Village (1976) (Delhi, 1988), p 249.

3 N. Kriger, "Popular Struggles in Zimbabwe's War of National Liberation", in P. Kaarsholm (ed.), Cultural Struggle \& Development in Southern Africa (London and Harare, 1991), pp 137-39. A rich material of insight into women's experiences of war and national liberation in Zimbabwe is offered by the thirty interviews in Irene Staunton (ed.), Mothers of the Revolution (Harare, 1990). On gender and cultural tradition in Rhodesia and Zimbabwe, cf. further the remarkable novel by Tsitsi Dangarembga, Nervous Conditions (London, 1988). 

the Social Sciences, vol. 9 (New York, 1968); C. Morse et al, Modernization by Design: social change in the twentieth century (New York, 1969). Cf. Max Weber, The Protestant Ethic and the Spirit of Capitalism (1920) (London, 1985), part 2, ch. 2.

6 Cf. Shula Marks, "The Origins of Ethnic Violence in South Africa" in P. Kaarsholm (ed.), Institutions, Culture and Change at Local Community Level, Occasional Paper No 3, International Development Studies, Roskilde, 1992.

7 "Der Skandinavismus besteht in der Begeisterung für die brutale, schmutzige, seeräuberische, altnordische Nationalität, für jene tiefe Innerlichkeit, die ihre überschwenglichen Gedanken und gefühle nicht in Worte bringen kaan, wohl aber in Taten, nämlich in Roheit gegen Frauenzimmer, permanente Betrunkenheit und mit tränenreicher Sentimentalität abwechselnde Berserkerwut." (Friedrich Engels, "Der dänisch-preussische Waffenstillstand", Neue Rheinische Zeitung, 10 September 1848, in Karl Marx and Friedrich Engels, Werke, vol. 5 [Berlin, 1975], p 394.) International Herald Tribune (Singapore edition), 2 March 1990.

9 See, for example, "Negotiations for Life and Democracy or Conflict and Destruction Message by the President: Mangosuthu G Buthelezi", Inkatha Freedom Party Annual General Conference, Ulundi, Saturday 20 July 1992.

10 Inkatha Freedom Party Constitution, n.d. (Ulundi, 1991), ch. 1, 1.12, p 2.

11 Cf. Paul Trewhela, "The Trial of Winnie Mandela", Searchlight South Africa, vol. 2. no. 3, July 1991.

12 Sudipta Kaviraj, "On State, Society and Discourse in India", in James Manor (ed.), Rethinking Third World Politics (London, 1992), pp 72-99, and Sudipta Kaviraj, "The Imaginary Institution of India", in P. Chatterjee and G. Pandey (eds.), Subaltern Studies, vol. VII (Delhi, 1992). Cf. Partha Chatterjee, "The Agenda for Nationalism", in P. Kaarsholm (ed.), Popular Movements, Political Organisation, Democracy and the State, Occasional Paper No 4, International Development Studies, Roskilde, (1992).

13 Cf. Veit Erlman, African Stars: Studies in Black South African Performance (Chicago, 1991). For mbube singing in Zimbabwe, see Preben Kaarsholm, "Mental Colonisation or Catharsis? Theatre, Democracy and Cultural Struggle from Rhodesia to Zimbabwe", Journal of Southern African Studies, vol. 16, no. 2, June 1990, p 256.

14 Listen, e.g., to the song "Stop Crying - Be a Man!" on the record Mbaqanga by Mahlathini and the Mahotella Queens (Gallo BL742, 1991).

15 Mzala, Buthelezi: Chief with a Double Agenda (London, 1988).

16 Joe Slovo, "Has Socialism Failed?" mimeograph, Johannesburg, 1989.

17 Albie Sachs, "Preparing for Freedom", Weekly Mail, 2 February 1990, reprinted in Ingrid de Kok and Karen Press (eds.), Spring is Rebellious: arguments about cultural freedom by Albie Sachs and respondents (Cape Town, 1990).

18 The Weekly Mail, New Nation and Vrye Weekblad campaigns revealing co-operation between Inkatha and the South African police and security forces were launched on 19 July 1991, on the eve of the Annual General Meeting of the Inkatha Freedom Party at Ulundi. Since then, almost every new issue of the journals has contained fresh testimonies and evidence of such a conspiracy of violent destabilization and its inspiration by similar murderous practices during the last years of Rhodesia and in Namibia and Mozambique in the 1980s. On this latter aspect, see, for example, Eddie Koch, "Dance Macabre of Colonels and Inyangas", Weekly Mail, vol. 8, no. 16, 16 April 1992, pp 6-7. On Inkatha involvement in attacks on Soweto commuter trains, see Linda Rulashe, "Witness 01 Tells of Inkatha Hit-Men", Weekly Mail, vol. 8, no. 21, 22 May 1992, p 5.

19 Another African society with an urgent need to come to terms with the ethnicization of politics is obviously Kenya, where, on the one hand, the opposition in the form of the Forum for Restoration of Democrary (FORD) is struggling with the development of non-ethnic criteria for party differentiation, while, on the other, the beleaguered Daniel arap Moi government seems to be resorting to strategies of promoting Kalenjin ethnic violence which are not unlike those activated in South Africa.

See Luke Mhlaba, "Local Cultures and Development in Zimbabwe: the case of Matabeleland", in Kaarsholm (ed.), Cultural Struggle and Development in Southern Africa, pp 209-225. 
21 Buthelezi, "Negotiations for Life and Democracy or Conflict and Destruction. Message by the President ...", op. cit., p 13. The special and direct relationship between "the Leader" and members of the Inkatha "Women's Brigade" is underlined similarly in the Inkatha Freedom Party Constitution, 7.

22 Ibid., p 12. Cf. Jeff Guy, "Ethnicity and Gender in Natal and Zululand", in the collection of papers presented at the workshop on "Gender and Ethnicity in a Modernising World", Copenhagen, February 1992. 